\title{
Definition of a coefficient to evaluate a moving contact pattern in planetary gearboxes
}

\author{
Andreas Fingerle ${ }^{1}$ (D) $\cdot$ Michael Otto $^{1}$ (D) $\cdot$ Karsten Stahl $^{1}$ \\ Received: 10 October 2019 / Published online: 29 June 2020 \\ (c) The Author(s) 2020
}

\begin{abstract}
Planetary gearboxes are often used for their high power density. Designs featuring a rotating carrier are popular because of their high gear ratio and potentially good efficiency. Especially in bigger constructions as in wind turbine gearboxes, it has been observed that the contact pattern moves in the width direction while the carrier rotates. This may lead to higher damage on the tooth flanks or reduced lifetime of the planet bearings underneath the mesh due to oscillating loads. The main influences on this phenomenon have yet to be investigated and no characteristic value has been defined to describe the moving contact pattern. It is only with this type of coefficient that the complex results of contact analysis can be evaluated clearly so that disadvantageous constructions can be distinguished from better ones. Therefore in this paper a coefficient to evaluate moving contact pattern is defined and used in a theoretical study about the influence of a radially displaced sun shaft on the contact pattern movement.
\end{abstract}

\section{Definition eines Koeffizienten zur Bewertung des Tragbildwanderns in Planetengetrieben}

\section{Zusammenfassung}

Planetengetriebe werden häufig aufgrund ihrer hohen Leistungsdichte genutzt. Konstruktionen mit rotierenden Planetenträger zeichnen sich dabei durch potentiell hohe Übersetzungen und hohe Wirkungsgrade aus. Insbesondere bei Großgetrieben, wie etwa in Windkraftanlagen, wurde bei rotierendem Planetenträger eine in Breitenrichtung wandernde Lastverteilung festgestellt. Tritt dieser Tragbildwandern genannte Effekt auf, ist ggf. mit höheren Zahnflankenschädigungen und reduzierter Lebensdauer der Planetenlager zu rechnen. Die Haupteinflüsse auf dieses Phänomen sind bisher nicht gezielt untersucht worden und es existiert kein Faktor zur Bewertung des Tragbildwanderns. Ein solcher Faktor ist hilfreich, um die komplexen Ergebnisse der Lastverteilungsberechnung einzuschätzen und unvorteilhafte Getriebekonstruktionen schnell und sicher zu erkennen. Daher wird in dieser Veröffentlichung der Tragbildwandernkoeffizient vorgestellt und in einer theoretischen Studie genutzt, um den Einfluss einer radial verschobenen Sonnenwelle auf das Tragbildwandern zu untersuchen.

\section{Introduction}

Andreas Fingerle

fingerle@fzg.mw.tum.de

Michael Otto

otto@fzg.mw.tum.de

Karsten Stahl

stahl@fzg.mw.tum.de

1 Department of Mechanical Engineering, Gear Research

Centre (FZG), Technical University of Munich,

Boltzmannstrasse 15, 85748 Garching b. Munich, Germany

Compared to spur gear stages, planetary gears have advantages regarding power density, potentially high efficiency and offer the possibility to use multi-shaft operation. Especially in large scale planetary gearboxes, like they are used in wind turbines, the phenomenon of the contact pattern moving between the left and right side of the flank as the carrier revolves can be observed [14, 15]. Fig. 1 shows the movement of the contact pattern in different carrier angles in the contact between sun and planet because of external influences. The tendency to increase power density in these gearboxes amplifies this effect due to larger elastic deformations of central shafts and housing. 
Fig. 1 Contact pressures and line loads of the sun-planet mesh in different angular positions of the carrier. (Adapted from [15])

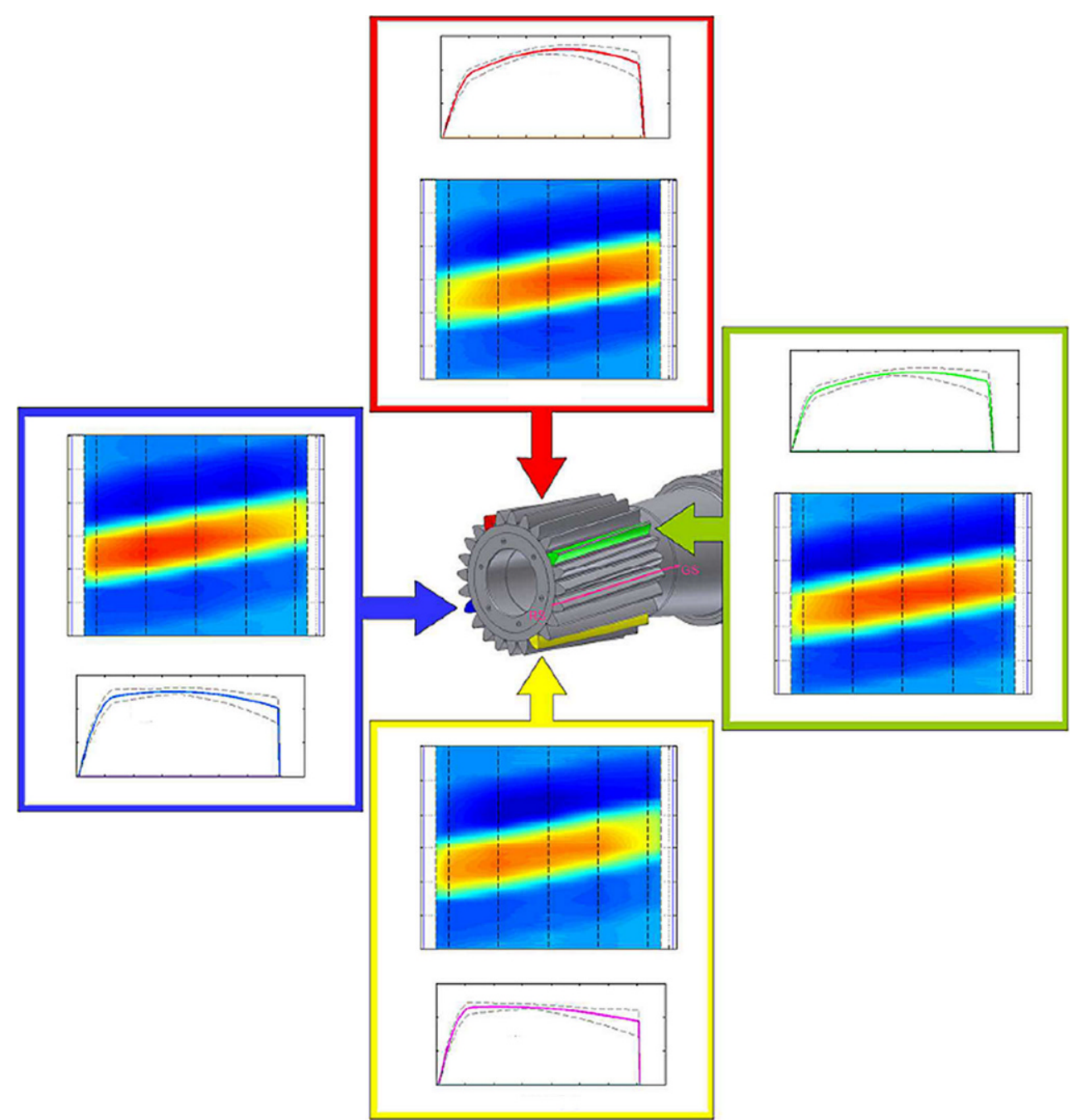

A load distribution that moves over the tooth width depending on the carrier angle cannot be sufficiently corrected by tooth modifications, which means that this phenomenon needs to be addressed early in the design process as it cannot be mended by the use of flank modifications. To observe the effect, the load distribution must first be measured. On spur and helical gears, load distribution and load sharing in planetary gears are usually measured with strain gauges. Becker [1] describes how face load factors $K_{H \beta}$ und $K_{F \beta}$ are determined by the use of strain gauges in the tooth root. Load sharing has been measured successfully with strain gauges in the tooth root of the sun gear or ring gear as well as on the front side of the ring gear by Hidaka, Kahraman, Boguski, Ligata, Singh and Nam [3, 9, 10, 13, 17, $18,24]$. Influences of planet pin positional error and ring gear thickness on load sharing were investigated in these papers. Terrin [26] analyzed the influence of lateral and angular planet pin errors on load distribution over the face width with strain gauges in the tooth root. A moving contact pattern was not detected in the tests. In rotating test rigs, the sun orbit can be measured with contactless distance sensors. Weinberger [29] describes a planetary gear test rig where the measurement of the sun orbit is possible with high time resolution. Strain gauges on the planet pin can be used to measure the load sharing between the planets. A moving contact pattern cannot be measured in the described configuration of the test rig. Load distribution over the face width is usually measured using multiple strain gauges applied to the tooth root like Kahraman, Nam and Kamps did [12, 14, 18]. In this case, it is limited by the space occupied by the strain gauges in the tooth root and the load distribution needs to be calculated from the tooth root extension. A method for this calculation was proposed by Paucker [21].

Only few publications mention contact pattern movement directly. Leimann described it in 2013 in a conference paper [15], but gives no explanation regarding which parameters might influence this behavior. Kamps [14] developed a complete finite-element model of a real wind turbine gearbox. Using this model, he investigated the in- 


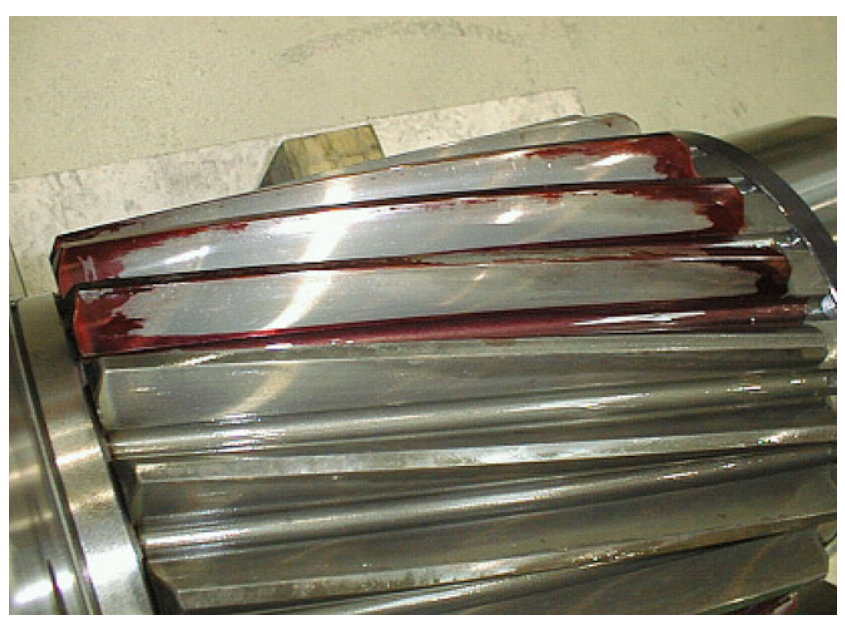

Fig. 2 A test with contact pattern dye implies a full contact pattern [14]

fluence of a housing that is tilted relative to the shafts due to its own mass. The ring gear that is integrated in the housing tilts with it and influences the load distribution in the planetary gear stage. The model has been validated with extensive measurements on actual gearboxes.

A test with contact pattern dye implied a full contact pattern (see Fig. 2) whereas the measurements clearly showed a moving contact pattern. The investigation focused on how a moving contact pattern influences the load of integrated planet bearings. While the tilted ring gear seems to be involved in the appearance of a moving contact pattern, Kamps does not express further possible influences and there are no remarks given as to how this phenomenon can be reduced in the design process of the gearbox.

Klein and Vriesen of Siemens AG applied for a patent in 2016 that describes the manufacturing of a ring gear where each tooth gets an individual modification instead of all teeth getting the same one. The patent states that this may help to accommodate the influences shaft weights exert on load distribution. The patent does not make specific statements regarding how big the influences of those transverse forces are on load distribution nor does it mention the effect of a moving contact pattern.

The usage of FEA for the simulation of whole gearboxes still needs a huge amount of calculation time and high effort to create highly detailed gearbox models. Therefore, more efficient calculation methods with analytical approaches are widely used. Zhang [30] investigated the influence of tilted planets on flank wear using an analytical model. Manufacturing deviations were analyzed by Bodas [2] using FEM contact simulation. Kahraman [11] built a dynamic model of a planetary gear stage based on springs and validated it with measurements [12]. A three-dimensional model was developed by Leque [16] to investigate the influences of manufacturing deviations. Another dynamic spring model was developed by Ren [23] to analyze the influences of pro- file deviations on the dynamic behavior of and load sharing in planetary gearboxes. Nejad [19] investigated the effect of radial and tangential pin position error on dynamic planet bearing loads using an MBS model. If applicable hybrid FE models like it was developed by Bonori [4] may be used to reduce calculation time.

In this article, the analytical gearbox calculation software RIKOR [7, 20, 22, 25, 27, 28] is used to calculate load distributions in planetary gears. The software was and is still developed as part of research projects financed by "Forschungsvereinigung Antriebstechnik e. V." (FVA) with the goal of calculating flank modifications for equal load distribution. The software considers deformation of teeth, shafts and bearings as well as housing stiffness. In the research projects FVA 592/I [8] and 592/II, RIKOR [5] has been systematically validated using static gearbox test rigs and a coordinate measuring machine. Fingerle designed a gearbox to investigate the phenomenon of a moving contact pattern with RIKOR in FVA project 592/III [6], which this publication is based on.

The phenomenon of a moving contact pattern is known in the gearbox industry and was documented in $[14,15]$ but there has been no scientific evaluation of parameters that influence the contact pattern movement. This paper aims to define a coefficient as a means to evaluate contact pattern movement and demonstrates the usage by analyzing an example gearbox.

\section{Definition of the contact pattern movement coefficient}

To evaluate contact pattern movement in a planetary gear stage, a coefficient needs to be determined. Ideally, the coefficient should be a normalized value that can be used to compare different gearbox designs. In this study, the calculation results from RIKOR are used to determine load distribution over the face width. The face width is normalized to the value of 1 to allow for the comparison of different gear designs. The midpoint of the tooth face is set as position 0 , whereas the left and right edges have the values -0.5 and 0.5 . RIKOR uses 18 equally distanced supporting points over the face width as the standard setting. The center of the area of the load distribution describes the position of the contact pattern. For the calculation, the centers of area $x_{s, i}$ of the 18 individual areas can be summarized to the center of area $x_{s}$ for the entire contact pattern:

$$
x_{s}=\frac{\sum_{i}\left(x_{s, i} \cdot A_{i}\right)}{\sum_{i}\left(A_{i}\right)}
$$


where $A_{i}=b_{i} \cdot L_{i}$ is the area of the individual sections. Because all sections are equally distanced and have the same width, the width $b_{i}$ can be canceled out. Therefore, the Load on each supporting point $L_{i}$ is directly usable.

$x_{s}=\frac{\sum_{i}\left(x_{s, i} \cdot L_{i}\right)}{\sum_{i}\left(L_{i}\right)}$

Fig. 3 shows an example of a load distribution. The load on each supporting point is shown as one beam. The center of area $x_{s}$ is marked with a red dotted line.

The center of area can be used to describe the one-sidedness of the load distribution and hereafter shall be called the center of contact. Due to the normalized face width, the center of contact can only have values between -0.5 and 0.5 . To evaluate a moving contact pattern, the center of contact for different angular planet carrier positions need to be calculated. The extreme values from these results are then used to obtain the contact pattern movement coefficient by subtracting the maximum value from the minimum value:

$c_{C P M}=x_{s, \max }-x_{s, \min }$

The resulting value will be called contact pattern movement coefficient $c_{C P M}$ and will be used in the following investigation to distinguish whether a parameter influences contact pattern movement. The value of $c_{C P M}$ may be between 0 and 1. $c_{C P M}=0$ means no movement of the contact pattern when the carrier rotates, whereas $c_{C P M}=1$ describes an extreme movement of the contact pattern from one edge of the tooth to the other. In practice, contact pattern movement coefficients values $c_{C P M} \ll 1$ are expected. It should be noted that this coefficient definition does not contain any information about the average one-sidedness of the contact pattern.

Fig. 4 shows an example for this approach with two onesided contact patterns representing the extreme values of load distribution while the carrier revolves, as well as their respective centers of contact (according to Eq. 2). Contact pattern movement coefficient $c_{C P M}$ is displayed as a green double-arrow. Its value is approximately $c_{C P M}=0.2$ and already describes severe contact pattern movement.

\section{Study on the influence of sun gear displacement on a moving contact pattern}

\subsection{Approach}

To investigate different influences on contact pattern movement, a static planetary gearbox test rig was designed that can be assembled in different configurations. A detailed calculation model of the gearbox was developed and a pa-
Fig. 3 Determination of the center of contact

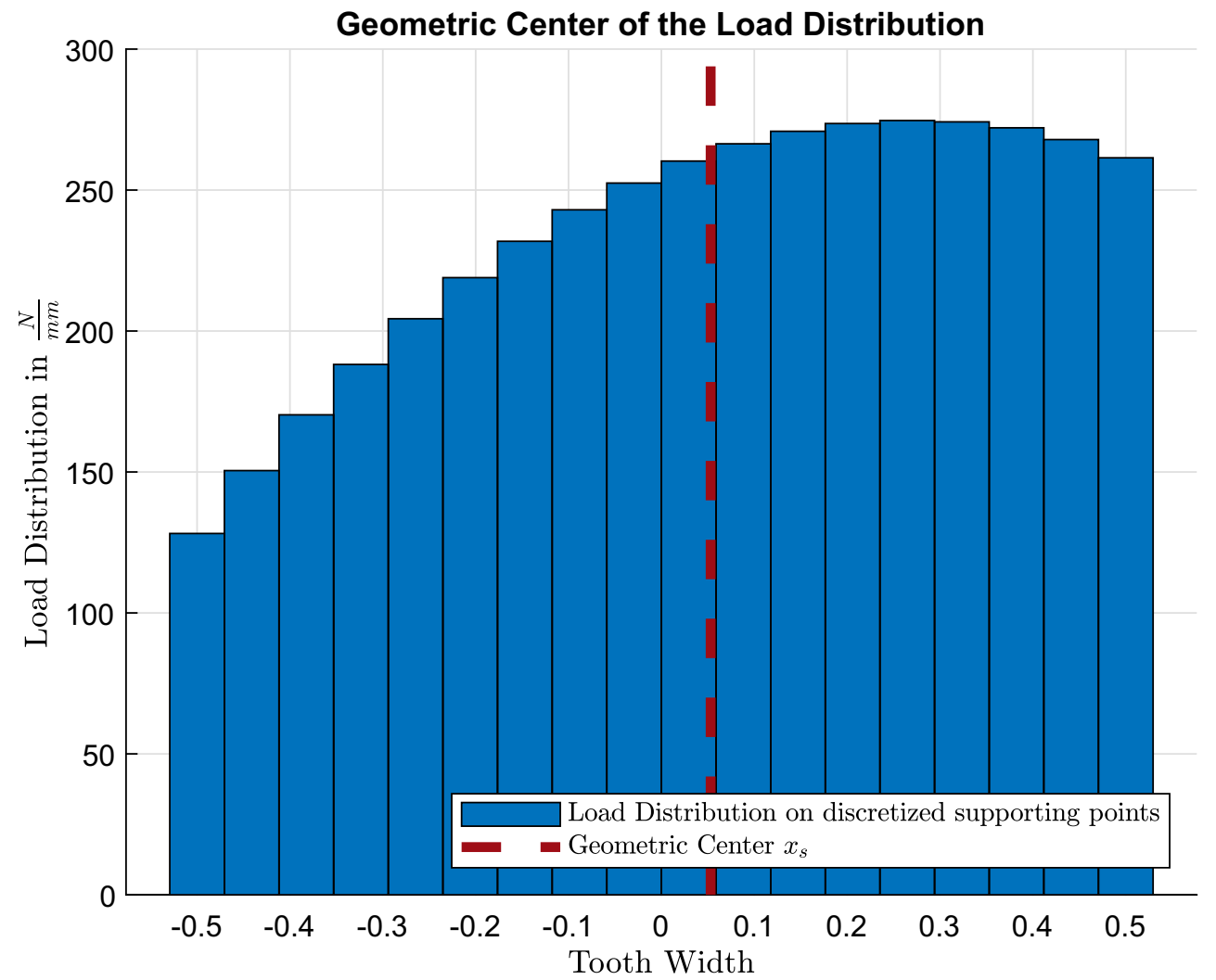


Fig. 4 Calculation of the contact pattern movement coefficient

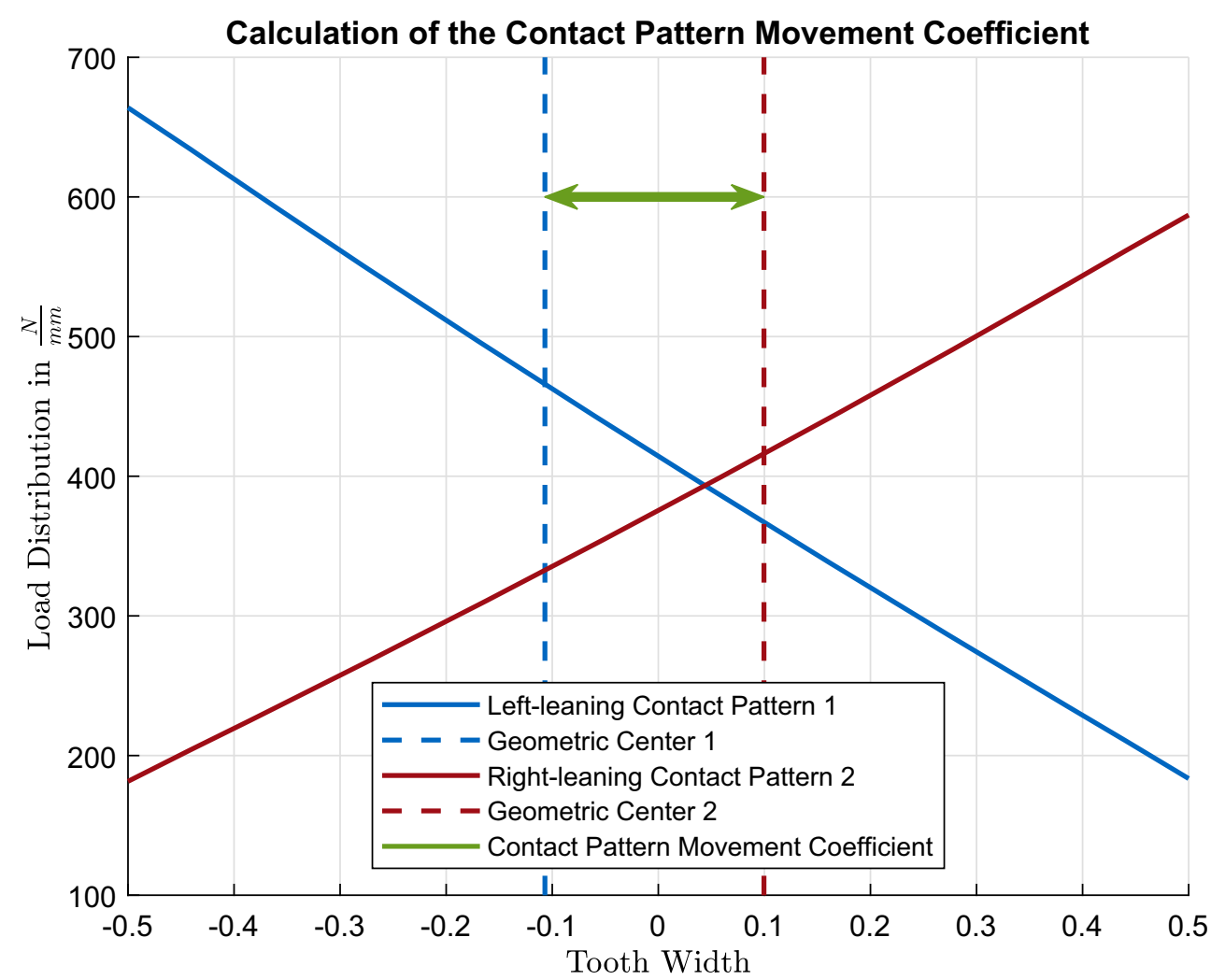

rameter study was performed. The gearbox was designed to fit on the institute's coordinate measuring machine and in the future can be manufactured to validate simulation results.

\subsection{Gearbox design}

Although the gearbox was especially designed to investigate and measure the phenomenon of a moving contact pattern, some boundaries had to be met. The dimensions of the gearbox are limited by the space the coordinate measuring machine can measure in. The teeth should be sufficiently big to allow for the application of strain gauges in the tooth root. Also, tooth tip clearance needs to be big enough to accommodate for strain gauges and cables. The test rig needs needs to be able to be assembled in different configurations. The following parameters can be changed on the test rig and therefore be investigated independently:

- No. of planets can be 3 or 5

- The bearings for all central shafts can be displaced radially and angularly.

- The carrier can be assembled with 1 or 2 plates

- The carrier can be made of different materials and therefore rigidities

The main data of the gearbox are shown in Table 1. The sun shaft serves as input and can be rotated to apply torque, and the ring gear is fixed in the housing while the carrier functions as the output shaft. The torque flow leads from the sun shaft to the carrier, while the ring gear is fixed in its housing. The design allows the carrier shaft to turn 45 degrees until it reaches a mechanical stop to allow shafts and gears to leave their rest position.

Fig. 5 shows a rendered image of the designed test rig. A concept of the tension mechanism is shown but is not considered in the following parameter study.

Main gearing data are displayed in Table 2. The common face width is comparatively wide considering the applied forces. This was designed to not only make the gears strong enough to withstand very one-sided face loads without failing, but to make the test rig deliberately prone to face width effects. An added advantage of wide teeth is that more strain gauges can be applied to the tooth root for better resolution on a real-life test rig.

Microgeometry of the teeth were determined based on RIKOR calculations. The design goal was that, in a gearbox configuration without deviations, an even load distribution over the face width would be reached at $50 \%$ of the design load. Therefore, helix angle modifications are applied to the sun and ring gear. To avoid high edge loads, a small amount of lead crowning is also applied. To account for high deflection values in the variation with one plated carrier, the modification in these cases have been adjusted. 


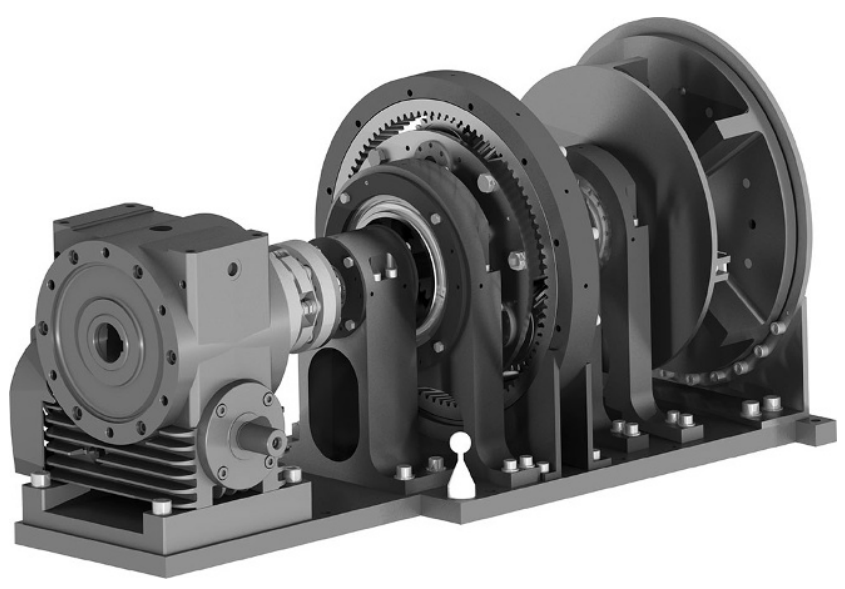

Fig. 5 Rendered image of the test gearbox

\subsection{Results}

\subsubsection{Process}

To investigate the influence of a displaced ring gear, different configurations of the test rig were simulated and contact pattern movement coefficients calculated. In the following investigation the contact sun gear and planet as well as planet and ring gear are examined separately by comparing configurations that only differ by one parameter. Table 3, for instance, shows that configurations $\mathrm{C} 01$ to $\mathrm{C} 04$ and $\mathrm{C} 05$ to $\mathrm{C} 08$ are identical except for the planet carrier stiffness.

\subsection{Ring gear displacement}

The influence of a displaced ring gear on contact pattern movement as was observed by Kamps [14] will be investigated by comparing the calculation results for various configurations. In the first case, the ring gear was radially moved in the direction of gravitation from its initial position; in the second case, it was tilted. In part, the results show extremely high contact pattern movement coefficients caused by the broad gears, comparatively low load and high deflection values. Furthermore, bearing clearances were not considered in the calculation. Fig. 6 shows the calculated contact pattern movement coefficients for the radially moved ring gear for both examined contacts. On the $\mathrm{X}$-axis, the compared configurations $\mathrm{C}$ according to Table 3 are outlined, whereas the $y$-axis shows the contact pattern
Table 1 Main gearbox data

\begin{tabular}{lccc}
\hline Name & Abb. & Unit & Value \\
\hline Stationary gear ratio & $i_{0}$ & - & -3 \\
Gear ratio sun to & $i_{1 s}$ & - & 4 \\
carrier & $T_{\text {in }}$ & Nm & 1800 \\
Max. input torque & $T_{\text {out }}$ & Nm & 7200 \\
Max. output torque & & &
\end{tabular}

Table 2 Main gear data

\begin{tabular}{lccc}
\hline Name & Abb. & Unit & Value \\
\hline Normal module & $m_{n}$ & $\mathrm{~mm}$ & 4.500 \\
Helix angle & $\beta$ & $\circ$ & 0 \\
Contact ratio & $\epsilon_{\alpha}$ & - & 1.247 \\
Center distance & $a$ & $\mathrm{~mm}$ & 135.0 \\
Common face & $b$ & $\mathrm{~mm}$ & 40 \\
width & & & \\
\hline
\end{tabular}

movement coefficient for each of the two compared configurations. The difference between those values shows how big the influence of a displaced ring gear is with this configuration.

As can be seen in Fig. 6a, the radially displaced ring gear heavily influences contact pattern movement. The influence is clearly higher with a two-plated carrier that is supported by bearings on each side as shown in the compared configurations C03-C04, C07-C08 and C11-C12. In configurations with a one-plated carrier, the influence is much smaller. This can be explained by observing central shaft deformation displayed in Fig. 7. The coordinate system is right handed with the axes $\mathrm{u}-\mathrm{v}-\mathrm{w}$, with $\mathrm{u}$ pointing axially to the shafts, the $v$-axis points in the direction of gravitation and $\mathrm{w}$ is perpendicular to the other axis. Root cause of the moving contact pattern is the deformed sun shaft due to the ring gear pushing the carrier and sun shaft down. While the two-plated carrier barely deforms, the oneplated carrier can adjust as a result of the missing bearing on the input side. It can be clearly seen that the misalignment between the two shafts in the area of the mesh is considerably smaller when the carrier is allowed to tilt. The tilting of the carrier is also the reason why the mesh with the ring gear is slightly worse in configurations with a oneplated carrier.

Tilting the ring gear leads to extremely high values in the contact pattern movement coefficient in the contact between

Table 3 Test rig configurations

\begin{tabular}{|c|c|c|c|c|c|c|c|c|c|c|c|c|}
\hline Configuration & $\mathrm{C} 01$ & $\mathrm{C} 02$ & $\mathrm{C} 03$ & $\mathrm{C} 04$ & $\mathrm{C} 05$ & $\mathrm{C} 06$ & $\mathrm{C} 07$ & $\mathrm{C} 08$ & $\mathrm{C} 09$ & $\mathrm{C} 10$ & $\mathrm{C} 11$ & $\mathrm{C} 12$ \\
\hline No. of Planets & \multicolumn{8}{|c|}{3} & \multicolumn{4}{|c|}{5} \\
\hline Central Shaft Displacement & $\mathrm{X}$ & $\checkmark$ & $\mathrm{X}$ & $\checkmark$ & $\mathrm{X}$ & $\checkmark$ & $\mathrm{X}$ & $\checkmark$ & $\mathrm{X}$ & $\checkmark$ & $\mathrm{X}$ & $\checkmark$ \\
\hline No. of Carrier Plates & & & & & & & & & & & & \\
\hline Stiffness of Carrier & \multicolumn{4}{|c|}{ High } & \multicolumn{4}{|c|}{ Low } & \multicolumn{4}{|c|}{ High } \\
\hline
\end{tabular}


a

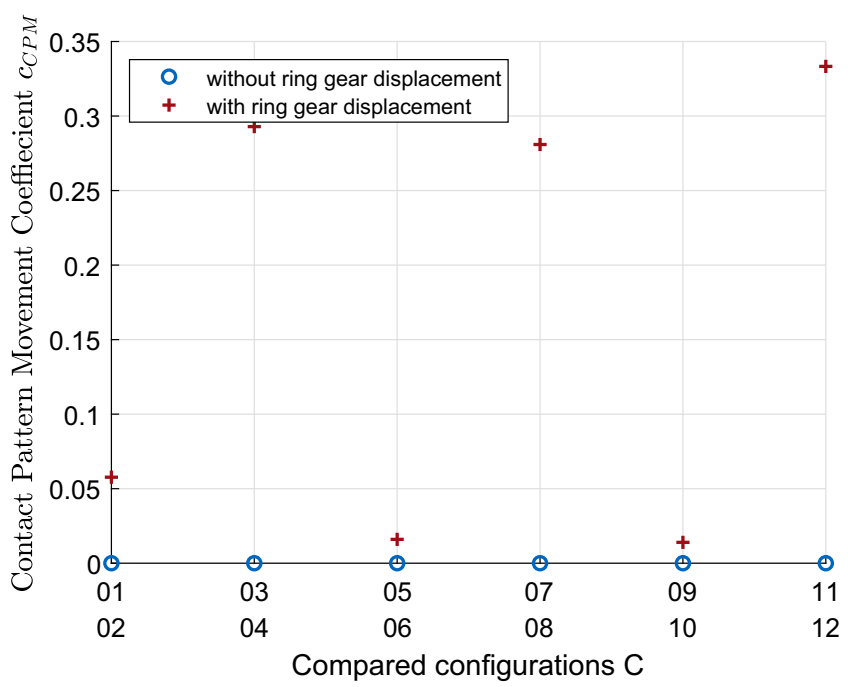

b

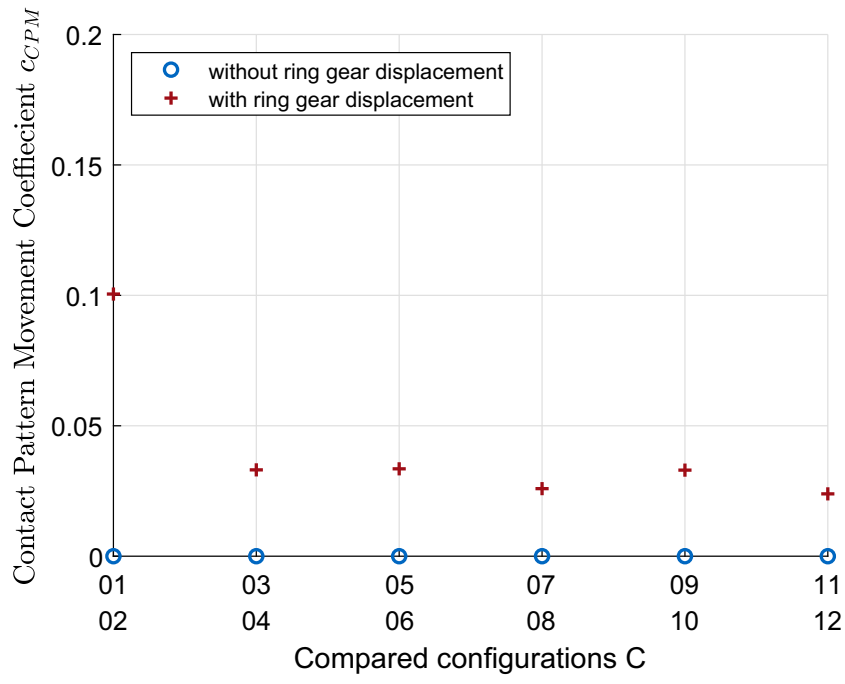

Fig. 6 Influence a radially displaced ring gear exerts on contact pattern movement. a Contact Sun - Planet, b Contact Planet - Ring Gear. Note: $\mathrm{y}$-axis individually scaled
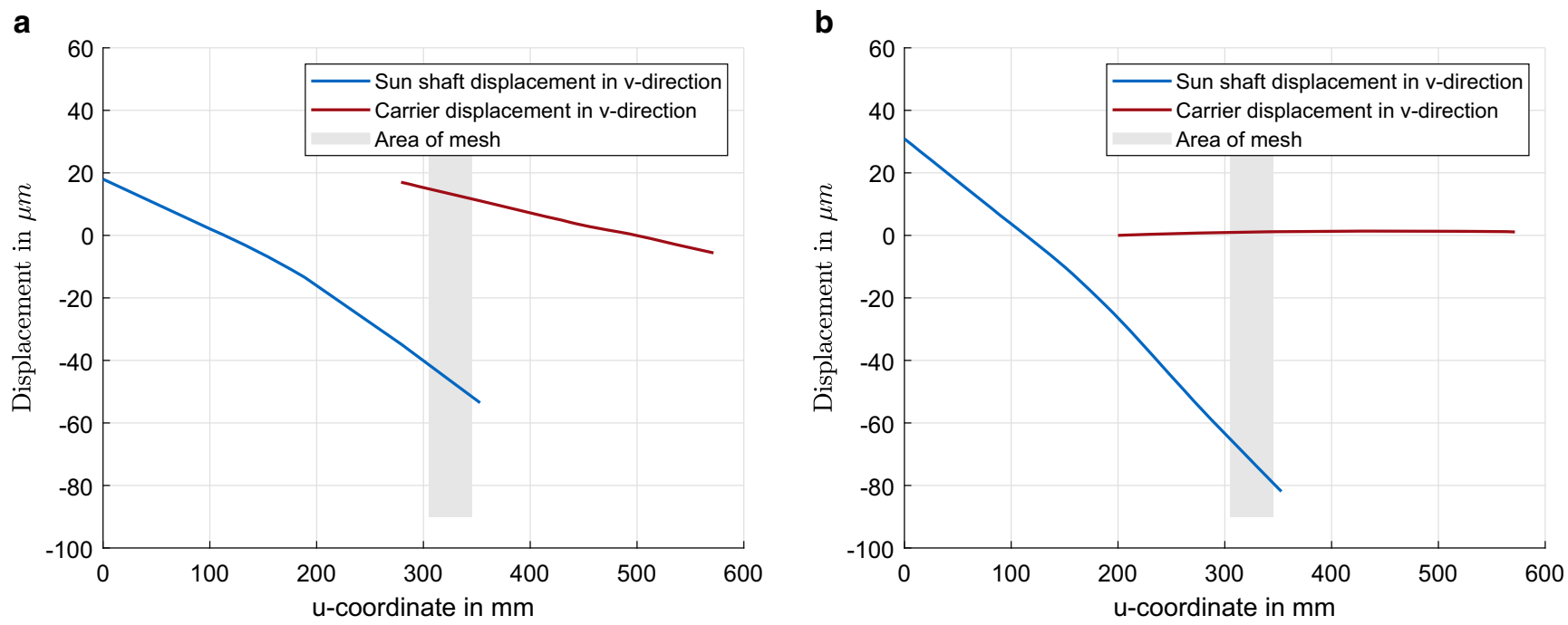

Fig. 7 Deformation of the central shafts due to a radially displaced ring gear. a One-plated Carrier, b Two-plated Carrier

planets and ring gear (see Fig. 8), which at least qualitatively matches the observed contact pattern movement in the investigations of Kamps [14]. The effects on the sun gear are much less severe.

\section{Conclusions}

In this publication, a coefficient was defined that can be used to evaluate contact pattern movement in planetary gearboxes. It is normalized so it can only end up with values between 0 and 1 independent of the gears used. The coefficient was then used to determine the influence of a displaced ring gear on contact pattern movement using a simulated test gearbox. The results clearly show that the displacement of the ring gear provokes a contact pattern movement in every investigated configuration. The amount of contact pattern movement depends heavily on the other parameters, such as the number of carrier plates. The investigation showed that the effect that has been observed in the wind turbine gearbox industry can be reproduced in simulations using FVA software RIKOR $\mathrm{K}$ and that it can be quantified with the introduced contact pattern movement coefficient $C_{C P M}$. In further investigations, the coefficient may be used to examine other possible influences on contact pattern movement, such as pin position error and helix 

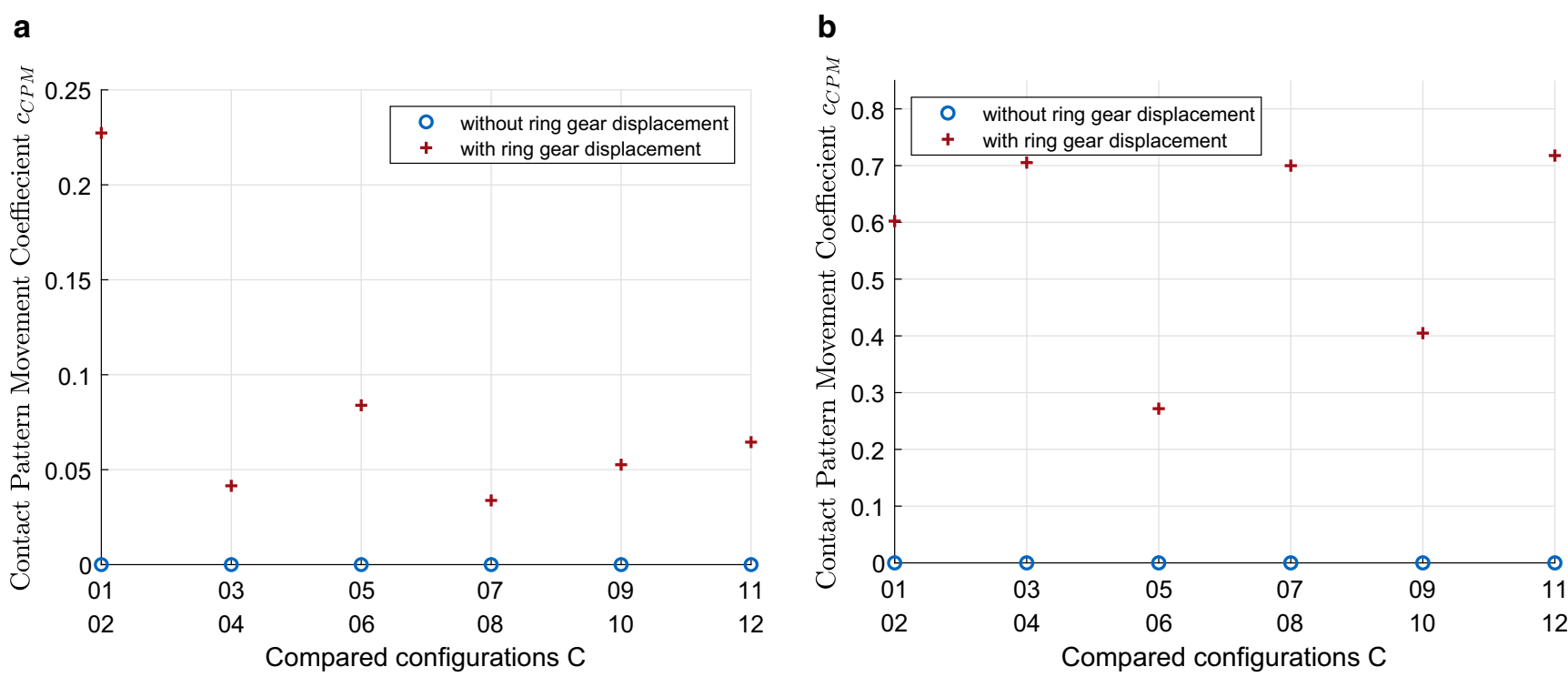

Fig. 8 Influence an angularly displaced ring gear exerts on contact pattern movement. a Contact Sun - Planet, b Contact Planet - Ring Gear. Note: $\mathrm{y}$-axis individually scaled

angle and therefore provide helpful information to avoid these effects in future gearbox designs.

Acknowledgements The contents of this paper have been developed during the research project FVA 592/III "Validierung RIKOR III". The research project has been financed with the financial means of Forschungsvereinigung Antriebstechnik e. V.

Funding Open Access funding provided by Projekt DEAL.

Conflict of interest The authors declare that they have no conflict of interest.

Open Access This article is licensed under a Creative Commons Attribution 4.0 International License, which permits use, sharing, adaptation, distribution and reproduction in any medium or format, as long as you give appropriate credit to the original author(s) and the source, provide a link to the Creative Commons licence, and indicate if changes were made. The images or other third party material in this article are included in the article's Creative Commons licence, unless indicated otherwise in a credit line to the material. If material is not included in the article's Creative Commons licence and your intended use is not permitted by statutory regulation or exceeds the permitted use, you will need to obtain permission directly from the copyright holder. To view a copy of this licence, visit http://creativecommons.org/licenses/by/4. $0 /$.

\section{References}

1. Becker E, Dorn G, Stammberger K (1991) Messung und Korrektur des Breitentragens von Zahneingriffen im Groß- und Sondergetriebebau. Antriebstechnik 30(8):45-49

2. Bodas A, Kahraman A (2004) Influence of carrier and gear manufacturing errors on the static load sharing behavior of planetary gear sets. JSME Int J Ser C 47(3):908-915. https://doi.org/10.1299/ jsmec. 47.908

3. Boguski B, Kahraman A, Nishino T (2012) A new method to measure planet load sharing and sun gear radial orbit of planetary gear sets. J Mech Des 134(7):71002. https://doi.org/10.1115/1.4006827
4. Bonori G, Barbieri M, Pellicano F (2008) Optimum profile modifications of spur gears by means of genetic algorithms. J Sound Vib 313(3):603-616. https://doi.org/10.1016/j.jsv.2007.12.013

5. Daffner M (2017) Validierung RIKOR: Weiterführende Validierung der Verformungsrechnung in RIKOR - Detaillierte Betrachtung einzelner Getriebeelemente: Forschungsvorhaben Nr. 592 II. FVA-Heft, vol 1232. Forschungsvereinigung Antriebstechnik e.V., Frankfurt

6. Fingerle A (2020) Validierung RIKOR: Validierung der Verformungsrechnung in RIKOR - Detaillierte Betrachtung gekoppelter Getriebesysteme: Forschungsvorhaben Nr. 592 III. FVA-Heft Nr., vol XXXX (not yet released). Forschungsvereinigung Antriebstechnik e.V., Frankfurt

7. Fingerle A, Hein M (2019) Methode zur Auslegung von Verzahnungskorrekturen unter Lastkollektivbelastung. Konstruktion 09: 78-81

8. Fürstenberger M (2011) Validierung Rikor: Validierung und Untersuchung von Anwendungsgrenzen des fva Getriebeprogramms rikor anhand von Verformungsmessungen: Forschungsvorhaben nr. 592. Fva Heft, vol 987. Forschungsvereinigung Antriebstechnik e.V., Frankfurt/Main

9. Hidaka T, Terauchi Y (1976) Dynamic behavior of planetary gear: 1st report load distribution in planetary gear. Bull JSME 19(132). https://doi.org/10.1299/jsme1958.19.690

10. Hidaka T, Terauchi Y, Nagamura K (1979) Dynamic behavior of planetary gear: 7 th report, influence of the thickness of the ring gear. Bull JSME 22(170). https://doi.org/10.1299/jsme1958.22.1142

11. Kahraman A (1994) Load sharing characteristics of planetary transmissions. Mech Mach Theory 29(8). https://doi.org/10.1016/0094114X(94)90006-X

12. Kahraman A (1999) Static load sharing characteristics of transmission planetary gear sets: model and experiment. SAE Tech Pap 1999-01-1050:233-241

13. Kahraman A, Ligata H, Singh A (2010) Influence of ring gear rim thickness on planetary gear set behavior. J Mech Des 132(2):21002. https://doi.org/10.1115/1.4000699

14. Kamps A, Klein-Hitpass A (2015) Einfluss von elastischen Verformungen auf die Auslegung und den Betrieb von Getrieben für Windkraftanlagen. In: Dresdner Maschinenelemente Kolloquium 
15. Leimann D (2013) Evolution in gar micro-geometry design for wind turbine gearboxes with respect to load distribution and noise and vibrations. In: VDI Wissensforum

16. Leque N, Kahraman A (2017) A three-dimensional load sharing model of planetary gear sets having manufacturing errors. J Mech Des 139(3):33302. https://doi.org/10.1115/1.4035554

17. Ligata H, Kahraman A, Singh A (2008) An experimental study of the influence of manufacturing errors on the planetary gear stresses and planet load sharing. J Mech Des 130(4):41701. https://doi.org/ 10.1115/1.2885194

18. Nam JS, Park YJ, Han JW, Nam YY, Lee GH (2016) The effects of non-torque loads on a three-point suspension gearbox for wind turbines. Int J Energy Res 40(5):618-631. https://doi.org/10.1002/ er.3373

19. Nejad AR, Xing Y, Guo Y, Keller J, Gao Z, Moan T (2015) Effects of floating sun gear in a wind turbine's planetary gearbox with geometrical imperfections. Wind Energy 18(12):2105-2120. https:// doi.org/10.1002/we. 1808

20. Neubauer B, Otto M, Stahl K (2015) Efficient calculation of load distribution and design of tooth flank modifications in planetary gear systems: static load and deformation analysis in a fully coupled mechanical model of a gear box structure with laplasn. In: VDI (ed) International Conference on Gears 2015, vol 1, pp 549-558

21. Paucker T, Otto M, Stahl K (2019) Determining the load distribution by measuring the tooth root stresses. Forsch Ingenieurwes 83(3):621-626. https://doi.org/10.1007/s10010-019-00349-2

22. Placzek T (1988) Lastverteilung und Flankenkorrektur in geradund schrägverzahnten Stirnradstufen. Dissertation. Technische Universität München, München
23. Ren F, Qin D, Lim TC, Lyu S (2014) Study on dynamic characteristics and load sharing of a herringbone planetary gear with manufacturing errors. Int J Precis Eng Manuf 15(9):1925-1934. https:// doi.org/10.1007/s12541-014-0547-y

24. Singh A, Kahraman A, Ligata H (2008) Internal gear strains and load sharing in planetary transmissions: model and experiments. J Mech Des 130. https://doi.org/10.1115/1.2890110

25. Stiller S (2013) Erweiterung Ritzelkorrekturprogramm (rikor) zur Bestimmung der Lastverteilung von Stirnradgetrieben. Fva heft, vol 1077. Forschungsvereinigung Antriebstechnik e.V, Frankfurt/Main

26. Terrin A, Lo Conte F, Meneghetti G (2018) Experimental evaluation of tooth-root bending strains of a sund gear in a planetary gear set for off-highway axles. In: Institut National des Sciences Appliquees (ed) International Gear Conference 2018, vol 2. Chartridge Books, Oxford, pp 1079-1088

27. Weinberger U, Glenk C (2017) Einbindung elastischer Gehäusestrukturen in die Getriebeauslegung mit Rikor und Visualisierung des Getriebegesamtsystems in der Fva-Workbench. Fva Heft, vol 1250. Forschungsvereinigung Antriebstechnik e.V., Frankfurt/Main

28. Weinberger U, Otto M, Stahl K (2020) Closed-form calculation of lead flank modification proposal for spur and helical gear stages. J Mech Des 142(3):31106. https://doi.org/10.1115/1.4045396

29. Weinberger U, Siglmüller F, Götz J, Otto M, Stahl K (2019) Scaling of planetary gear stages according to gear excitation similarity. Proc Inst Mech Eng Part C. https://doi.org/10.1177/0954406219851828

30. Zhang J, Wang T, Chen T (2018) The effect of axis misalignment on gear wear in planetary gear trains. In: Institut National des Sciences Appliquees (ed) International Gear Conference 2018. Chartridge Books, Oxford, pp 1066-1078 